\title{
Experimental Infection of Aedes albopictus (Diptera: Culicidae) Larvae with the Xiphidiocercariae of a Hematolechid
}

\author{
Gílcia Aparecida de Carvalho, Carlos Fernando S Andrade $/{ }^{+}$, Marlene Tiduko Ueta*
}

Departamento de Zoologia *Departamento de Parasitologia, Instituto de Biologia, Universidade Estadual de Campinas,
Caixa Postal 6109, 13084-971 Campinas, SP, Brasil

Aedes albopictus larvae were exposed, either individually or in groups, to different concentrations of xiphidiocercariae of Haematoloechus sp. for parasitological studies. It was observed the acute lethal effect and some aspects of the host-parasite relationship, such as delay or progress in the host life cycle, the number and location of the metacercariae in the host, adult host malformations and the amount of metacercariae required to cause death. A delay in the cycle and a high mortality rate was in general observed. Inside the larvae, the metacercariae were found predominantly in the thorax, abdominal segments and in the head, along with a reduced number in the anal lobe and cervix. It was shown that in addition to the quantity of metacercariae present, their location in the larvae was also relevant in the determination of mortality and anomalies. Malformed adults developed from larvae containing from one to three metacercariae.

Key words: Aedes albopictus - parasitism - xiphidiocercariae - metacercariae - Haematoloechus sp.

The larval control of mosquitoes belonging to the genus Aedes, such as Ae. aegypti and Ae. albopictus, have been attempted with a great number of predators including copepods, planarians, various types of aquatic insects and small fishes (Kay et al. 1992, Lacey \& Orr 1994, Andrade 1995, Melo et al. 1996). Several larval parasites of these mosquitoes are also known, which can be used for their biological control, including protozoans and metazoans such as the mermithid nematodes (Petersen 1973, Finney 1979, Hominick \& Tingley 1984). The entomophylic xiphidiocercariae of digenetic trematodes such as Prosthogonimus spp. and Plagiorchis spp. have also been indicated as efficient in the larval control of mosquitoes such as Culex quinquefasciatus, Ae. aegypti and Anopheles quadrimaculatus (Rao et al. 1985, Webber et al. 1987a,b,c, Dempster \& Rau 1991, Zakikhani \& Rau 1999). The xiphidiocercariae are assexually produced in sporocysts inside of the hepatopancreas of snails of the genus Lymnaea. These snails take part in the cycle of the trematodes as the first intermediary hosts (Blankespoor 1977). The snails liberate the cercariae, which penetrate and encyst in the larvae or nymphs of aquatic insects. Such insects participate in the cycle as secondary intermediary hosts.

Details on the parasite-host interaction between xiphidiocercariae and mosquito larvae are rare. Busta and Nasincova (1986) showed experimentally that the larvae of mosquitoes such as Culex and Dixa or even blackfly

This study was part of a thesis presented by GAC to the Instituto de Biologia, Unicamp, in partial fulfilment of the requirements for the MSc's degree.

${ }^{+}$Corresponding author. Fax: +55-19-3289.3124. E-mail: cfeandra@unicamp.br; giacs@ zipmail.com.br

Received 16 July 2001

Accepted 5 November 2001 larvae could be the secondary intermediary hosts of Plagiorchis neomidas. Cercariae of other plagiorchid species penetrate and encyst in chironomid larvae (Yoder \& Coggins 1998). According to Van Theil (1930) and Dollfus et al. (1960), xiphidiocercariae of hematolechid trematodes also encyst in mosquito larvae. Rau et al. (1991) observed that when larvae of Ae. provocans were exposed to the cercariae of $P$. noblei under field conditions, there was a reduction in the number of pupae produced due to the mortality caused by xiphidiocercariae in the 1 st, 2 nd and 3 rd instar larvae. They also found that larvae with more than two metacercariae rarely survived.

In a recent study, Carvalho et al. (2001a) evaluated the susceptibility to larvae of Ae. albopictus, Ae. aegypti and $C x$. quinquefasciatus, when exposed in groups to xiphidiocercariae. In another papers it was reported the finding of snails infected with such entomopathogenic xiphidiocercariae, including the morphometrical characterization and biological studies of these cercariae (Carvalho et al. 2001b, c). The present study aimed the evaluation of the parasitism in last instar larvae of Ae. albopictus, when exposed individually or in groups to the xiphidiocercariae of Haematoloechus sp. The development of the infected larvae was observed under laboratory conditions and it was recorded mortality rates, the time of imature development and the number and location of the encysting metacercariae.

\section{MATERIALS AND METHODS}

Ae. albopictus larvae were exposed individually or in groups to xiphidiocercariae of the trematode Haematoloechus sp., obtained from the natural infection of Lymnaea columella collected in a cattle raising pasture in Miracatu, São Paulo (Vale do Ribeira), from September 1996 to February 1999 (details in Carvalho et al. 2001b). All the observations were carried out under laboratory conditions of $25 \pm 2^{\circ} \mathrm{C}$ and $80 \%$ relative humidity.

Larvae at the beginning of the last instar were always used, obtained from the Aal-Unicamp colony (Dept. of 
Zoology, Universidade Estadual de Campinas). This colony was stablished from mosquitoes field collected in the university campus from 1991 to 1995.

The exposition of individual larva to the xiphidiocercariae was effected in flasks containing $6 \mathrm{ml}$ of dechlorinated tap water. Larger flasks containing $40 \mathrm{ml}$ of dechlorinated water were used for the experiments with grouped larvae. In this late case, after $24 \mathrm{~h}$ of exposition the larvae were separated and individually transferred to that flasks containing $6 \mathrm{ml}$ of water. The larvae were fed twice weekly on a mixture of beer yeast extract, powdered liver and sucrose (10:3:2). The reposition of evaporated water in the flasks was effected in order to maintain the initial volume.

When individually treated, the larvae were exposed to two concentrations of xiphidiocercariae: 10 or 5 per larva (respectively equivalent to 1.66 and 0.83 xiphidiocercariae/ $\mathrm{ml}$ ). For the higher concentration (10 xiphidiocercariae/ larva), three replicates were carried out exposing respectively 20, 60 and $70 \mathrm{Ae}$. albopictus larvae. For the lower concentration 60 larvae were used in just one replicate.

When treated in group, for $24 \mathrm{~h}$, larvae were exposed to only one concentration of xiphidiocercariae per larva, equivalent to 10 per larva (or 10 per $\mathrm{ml}$ ), in two repetitions with 40 individuals each. After $24 \mathrm{~h}$ of exposition, a count of formed and developed metacercariae was always performed, and its location within each larva and/or pupa was registered. Mortality was accompanied daily as well as the larval development time and the time for adult emer- gence. In addition, larvae, pupae and adults were observed under a light microscope to determine the intensity and consequences of the infection.

Life cycle of the treated mosquitoes were compared with those of the control group (20 individuals) using the Student " $\mathrm{t}$ " Test $(\mathrm{p}=0.05)$.

\section{RESULTS}

Individualized exposition to 10 xiphidiocercariae (1.66 xiphidiocercariae/ml) - All the larvae were infected and, on average, $24.2 \%(\mathrm{SD}=4.0)$ of the cercariae formed cysts in the mosquito larvae. The cycle was delayed with mortality occurring up to 65 days after infection. The emergence of only $42 \%$ of adults occurred between 9.5 and 12.5 days after exposition (Table I). When dissected, these adults were also shown to be infected.

The number of metacercariae found in the $A e$. albopictus larvae varied from 1 to 8 , and were found in different places of the body. The greatest number of xiphidiocercariae were found in the thorax, followed by those in the abdomen (Fig.), head, anal lobe and cervix. The emergence of infected adults occurred in individuals carrying up to four metacercariae as larvae. Of these adults (total of 63), only five were malformed, being three unable to separate from their own exuviae, one with an abnormal wing and the last with both wings undeveloped. The three adults which emerged stuck to their exuviae and the adult with atrophied wing, developed from larvae carrying only one metacercariae located in the thorax. That adult which

TABLE I

Mean results (standard deviation) for xiphidiocercariae parasitism in individualized Aedes albopictus late instar larvae (10 cercariae/larvae or 1.66 cercariae/ml). Number of cercariae per larvae, localization, fate and mean number of days for adult emergence

\begin{tabular}{|c|c|c|c|c|c|c|c|c|c|c|c|}
\hline \multirow{2}{*}{$\begin{array}{l}\text { No. } \\
\text { metac. } \\
\text { per } \\
\text { larva } \\
\end{array}$} & \multirow{2}{*}{$\begin{array}{c}\text { Occur- } \\
\text { rence } \\
\% \\
\end{array}$} & \multicolumn{5}{|c|}{ Localization in larva \% } & \multicolumn{3}{|c|}{$\%$ deaths in } & \multirow{2}{*}{$\begin{array}{c}\% \\
\text { adult } \\
\text { emergence }\end{array}$} & \multirow{2}{*}{$\begin{array}{c}\text { Mean } \\
\text { days f/ } \\
\text { emergence }\end{array}$} \\
\hline & & ce & he & th & $a b$ & al & $\mathrm{L}_{4}$ & PP & $\mathrm{P}$ & & \\
\hline 1 & $\begin{array}{c}35 \\
(8.6)\end{array}$ & $\begin{array}{l}0 \\
-\end{array}$ & $\begin{array}{c}2.5 \\
(0.7)\end{array}$ & $\begin{array}{c}8.2 \\
(4.6)\end{array}$ & $\begin{array}{c}4.3 \\
(1.4)\end{array}$ & $\begin{array}{c}0.2 \\
(0.3)\end{array}$ & $\begin{array}{c}7.9 \\
(8.6)\end{array}$ & $\begin{array}{c}3.7 \\
(4.2)\end{array}$ & $\begin{array}{c}1 \\
(1.6)\end{array}$ & $\begin{array}{c}22.3 \\
(11.9)\end{array}$ & $\begin{array}{l}9.5 \\
(3)\end{array}$ \\
\hline 2 & $\begin{array}{l}27.6 \\
(2.9)\end{array}$ & $\begin{array}{l}0 \\
-\end{array}$ & $\begin{array}{l}4.4 \\
(3)\end{array}$ & $\begin{array}{c}9 \\
(2.4)\end{array}$ & $\begin{array}{c}8.8 \\
(0.9)\end{array}$ & $\begin{array}{c}1.1 \\
(0.7)\end{array}$ & $\begin{array}{l}11.8 \\
(6.8)\end{array}$ & $\begin{array}{c}4.3 \\
(1.2)\end{array}$ & $\begin{array}{l}0 \\
-\end{array}$ & $\begin{array}{l}11.5 \\
(8.5)\end{array}$ & $\begin{array}{l}12.5 \\
(2.9)\end{array}$ \\
\hline 3 & $\begin{array}{l}15.1 \\
(4.4)\end{array}$ & $\begin{array}{c}0.2 \\
(0.3)\end{array}$ & $\begin{array}{c}2.3 \\
(2.1)\end{array}$ & $\begin{array}{c}7.8 \\
(2.1)\end{array}$ & $\begin{array}{c}8.7 \\
(2.9)\end{array}$ & $\begin{array}{c}0.6 \\
(0.9)\end{array}$ & $\begin{array}{c}5 \\
(5)\end{array}$ & $\begin{array}{c}3.1 \\
(2.7)\end{array}$ & $\begin{array}{c}1 \\
(0.9)\end{array}$ & $\begin{array}{c}6 \\
(4.3)\end{array}$ & $\begin{array}{l}12.3 \\
(3.5)\end{array}$ \\
\hline 4 & $\begin{array}{l}12.5 \\
(8.4)\end{array}$ & $\begin{array}{c}0.2 \\
(0.3)\end{array}$ & $\begin{array}{c}2 \\
(0.4)\end{array}$ & $\begin{array}{c}7.1 \\
(3.9)\end{array}$ & $\begin{array}{c}9.8 \\
(9.4)\end{array}$ & $\begin{array}{c}0.6 \\
(0.5)\end{array}$ & $\begin{array}{c}8.2 \\
(4.3)\end{array}$ & $\begin{array}{c}1.7 \\
(2.8)\end{array}$ & $\begin{array}{c}0.5 \\
(0.8)\end{array}$ & $\begin{array}{c}2.2 \\
(2.5)\end{array}$ & $\begin{array}{c}11.7 \\
(13.8)\end{array}$ \\
\hline 5 & $\begin{array}{c}4.7 \\
(1.2)\end{array}$ & $\begin{array}{l}0 \\
-\end{array}$ & $\begin{array}{c}1 \\
(1.3)\end{array}$ & $\begin{array}{l}4.1 \\
(2)\end{array}$ & $\begin{array}{c}3.2 \\
(2.9)\end{array}$ & $\begin{array}{c}1.4 \\
(1.1)\end{array}$ & $\begin{array}{c}4.7 \\
(1.2)\end{array}$ & $\begin{array}{l}0 \\
-\end{array}$ & $\begin{array}{l}0 \\
-\end{array}$ & & \\
\hline 6 & $\begin{array}{c}3.6 \\
(1.7)\end{array}$ & $\begin{array}{l}0 \\
-\end{array}$ & $\begin{array}{c}3.6 \\
(3.7)\end{array}$ & $\begin{array}{c}2.8 \\
(1.6)\end{array}$ & $\begin{array}{c}1.5 \\
(1.9)\end{array}$ & $\begin{array}{l}0.8 \\
(1)\end{array}$ & $\begin{array}{c}2.6 \\
(2.5)\end{array}$ & $\begin{array}{c}1 \\
(0.9)\end{array}$ & $\begin{array}{l}0 \\
-\end{array}$ & & \\
\hline 7 & $\begin{array}{c}1 \\
(1.6)\end{array}$ & $\begin{array}{l}0 \\
-\end{array}$ & $\begin{array}{c}0.3 \\
(0.3)\end{array}$ & $\begin{array}{c}0.9 \\
(1.5)\end{array}$ & $\begin{array}{c}1.2 \\
(2.1)\end{array}$ & $\begin{array}{l}0 \\
-\end{array}$ & $\begin{array}{c}1 \\
(1.6)\end{array}$ & $\begin{array}{l}0 \\
-\end{array}$ & $\begin{array}{l}0 \\
-\end{array}$ & & \\
\hline 8 & $\begin{array}{c}0.5 \\
(0.8)\end{array}$ & $\begin{array}{l}0 \\
-\end{array}$ & $\begin{array}{c}0.5 \\
(0.5)\end{array}$ & $\begin{array}{c}0.2 \\
(0.3)\end{array}$ & $\begin{array}{c}0.7 \\
(1.2)\end{array}$ & $\begin{array}{l}0 \\
-\end{array}$ & $\begin{array}{c}0.5 \\
(0.8)\end{array}$ & $\begin{array}{l}0 \\
-\end{array}$ & $\begin{array}{l}0 \\
-\end{array}$ & & \\
\hline Total & 100 & 0.4 & 16.6 & 40.1 & 38.2 & 4.7 & 41.7 & 13.8 & 2.5 & 42 & \\
\hline
\end{tabular}

ce: cervix; he: head; th: thorax; ab: abdominal segms.; al: anal lobe; metac: metacercariae; $\mathrm{L}_{4}$ : larvae; PP: pre-pupa; P: pupa 
emerged with problem in both wings developed from a larva infected with three metacercariae, two in the thorax and the other in the third abdominal segment.

The time to reach the adult stage for the first replicate was not significantly different from the control group, but development significantly delayed (respectively 1.42 and 1.67 times) for the second and third replicates.
Individualized exposition to five xiphidiocercariae (0.83 xiphidiocercariae $/ \mathrm{ml})$ - In this experiment, with a concentration half of that used previously, there was also $100 \%$ infection of the larvae and 34 adults emerged between 9 and 23 days after exposition (Table II). The final rate of mortality was $43.4 \%$, starting three days after infection and extending up to the 35 th day.
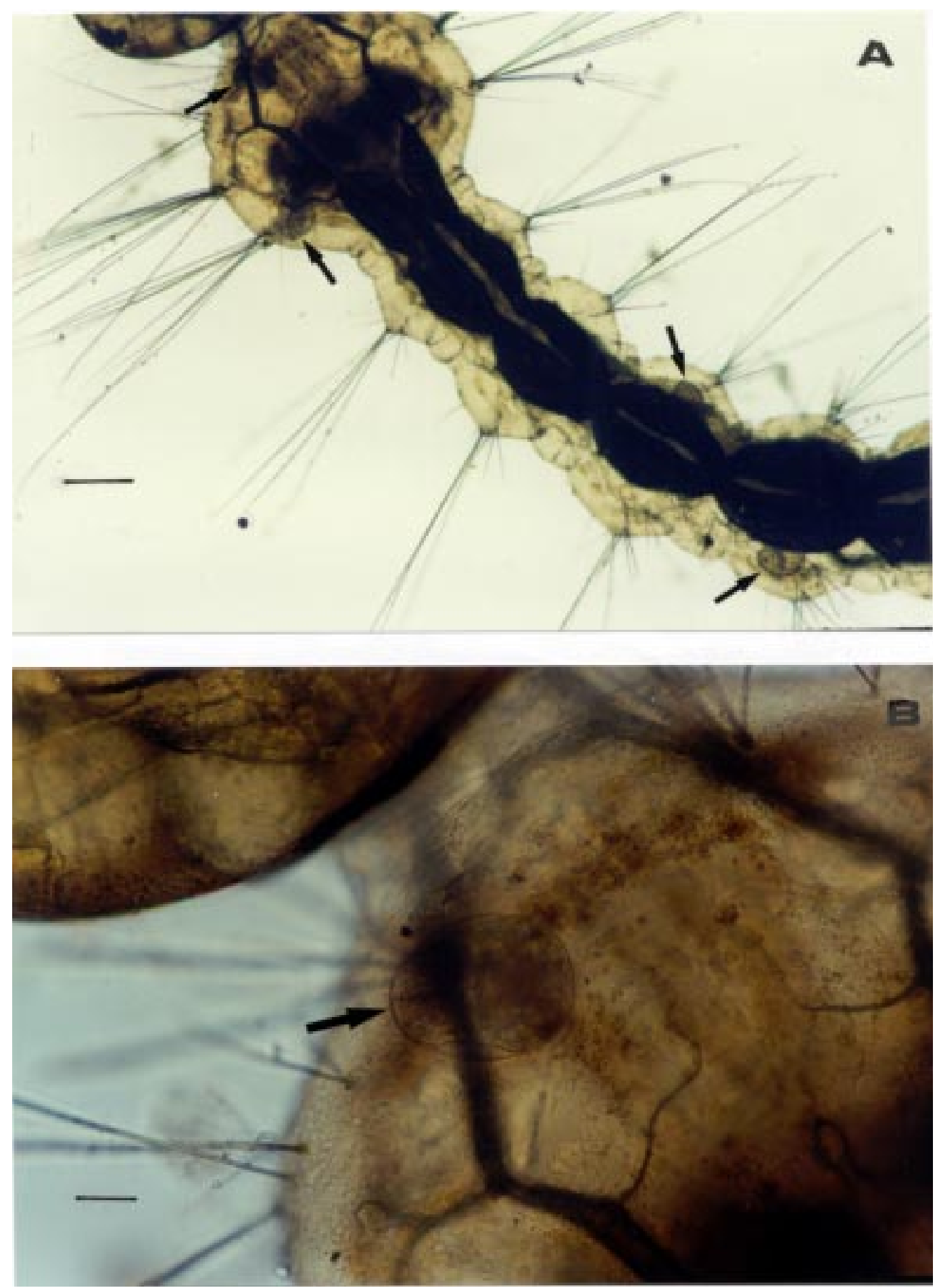

Fourth instar Aedes albopictus larvae parasitized by Haematoloechus sp. metacercariae. Bar $=250 \mu \mathrm{m}(\mathrm{A}) ; 50 \mu \mathrm{m}$ (B) 
The number of metacercariae found in the larvae of Ae. albopictus varied from 1 to 4 (Table II), with the majority of infected adults (46.5\%) arising from larvae with only one metacercaria.

In the same way as in the previous experiment, the development of the larvae was also delayed. When compared to the control, the development time of the larvae which reached the adult stage was 1.42 times higher.

Grouped exposition to ten xiphidiocercariae/ml (24 h) followed by individualization - In this experiment with grouped larvae there was an accentuated mortality, similar to that obtained in the previous experiments with larvae individually exposed. More than $60 \%$ of the larvae died between the 1st and 16th days after exposition (Table III). Adult mosquitoes which otherwise emerged (38.7\%) took a mean time of between 3.5 and about 6.8 days, depending on the number of cercariae which penetrated in the larval stage.
After grouped exposition for $24 \mathrm{~h}$, the larvae were separated and accompanied individually. Parasitism was $100 \%$, with larvae possessing from 1 to 4 metacercariae predominantly in the thorax, followed by in the abdominal segments, head, anal lobe and cervix (Table III). Adult emergence occurred when the larvae were infected with no more than three metacercariae. Of the adults which emerged, three presented malformations and died: one with both wings deformed and the other two with the wings stuck to their pupal exuviae. Related to these two adults which were unable to free themselves from their exuviae, one developed from a larva with three metacercariae, one in the thorax and the other two in the third and the seventh abdominal segments. The other larvae presented only one metacercaria, but in the thorax.

There was a statistically significant progress (1.2 times) in the development time of the larvae into adults as compared to the control larvae.

\section{TABLE II}

Results for xiphidiocercariae parasitism in individualised Aedes albopictus late instar larvae ( 5 cercariae/larvae or 0.83 cercariae/ $\mathrm{ml}$ ). Number of cercariae per larvae, localization, fate and mean number of days for adult emergence

\begin{tabular}{|c|c|c|c|c|c|c|c|c|c|c|c|}
\hline \multirow{2}{*}{$\begin{array}{l}\text { No. } \\
\text { metac } \\
\text { per } \\
\text { larva } \\
\end{array}$} & \multirow{2}{*}{$\begin{array}{c}\text { Occur- } \\
\text { rence } \\
\% \\
\end{array}$} & \multicolumn{5}{|c|}{ Localization in larva $\%$} & \multicolumn{3}{|c|}{$\%$ deaths in } & \multirow{2}{*}{$\begin{array}{c}\% \\
\text { adult } \\
\text { emergence }\end{array}$} & \multirow{2}{*}{$\begin{array}{c}\text { Mean } \\
\text { days f/ } \\
\text { emergence }\end{array}$} \\
\hline & & ce & he & th & $\mathrm{ab}$ & al & $\mathrm{L}_{4}$ & $\mathrm{PP}$ & $\mathrm{P}$ & & \\
\hline 1 & 61.7 & 0 & 14.9 & 11.7 & 12.8 & 0 & 13.3 & 0 & 1.7 & 46.5 & $\begin{array}{c}12 \\
(4.9)\end{array}$ \\
\hline 2 & 25 & 0 & 11.7 & 10.6 & 7.4 & 2.1 & 16.6 & 1.7 & 0 & 6.7 & $\begin{array}{c}9 \\
(6)\end{array}$ \\
\hline 3 & 8.3 & 0 & 8.5 & 2.1 & 5.3 & 0 & 6.7 & 0 & 0 & 1.7 & $\begin{array}{l}20 \\
(0)\end{array}$ \\
\hline 4 & 5 & 0 & 3.2 & 4.3 & 4.3 & 1.1 & 1.7 & 1.7 & 0 & 1.7 & $\begin{array}{l}23 \\
(0)\end{array}$ \\
\hline Total & 100 & 0 & 38.3 & 28.7 & 29.8 & 3.2 & 38.3 & 3.4 & 1.7 & 56.6 & \\
\hline
\end{tabular}

ce: cervix; he: head; th: thorax; ab: abdominal segms.; al: anal lobe; metac: metacercariae; $\mathrm{L}_{4}$ : larvae; PP: pre-pupa; P: pupa

TABLE III

Mean results (standard deviation) for xiphidiocercariae parasitism in Aedes albopictus, late instar larvae (10 cercariae/larvae or 10 cercariae/ml), grouped for $24 \mathrm{~h}$. Number of cercariae per larvae, localization, fate and mean number of days for adult emergence

\begin{tabular}{|c|c|c|c|c|c|c|c|c|c|c|c|}
\hline \multirow{2}{*}{$\begin{array}{l}\text { No. } \\
\text { metac } \\
\text { per } \\
\text { larva } \\
\end{array}$} & \multirow{2}{*}{$\begin{array}{c}\text { Occur- } \\
\text { rence } \\
\%\end{array}$} & \multicolumn{5}{|c|}{ Localization in larva $\%$} & \multicolumn{3}{|c|}{$\%$ deaths in } & \multirow{2}{*}{$\begin{array}{c}\% \\
\text { adult } \\
\text { emergence }\end{array}$} & \multirow{2}{*}{$\begin{array}{c}\text { Mean } \\
\text { days f/ } \\
\text { emergence } \\
\end{array}$} \\
\hline & & ce & he & th & $a b$ & $\mathrm{al}$ & $\mathrm{L}_{4}$ & $\mathrm{PP}$ & $\mathrm{P}$ & & \\
\hline 1 & $\begin{array}{c}62.5 \\
(10.6)\end{array}$ & $\begin{array}{l}0 \\
-\end{array}$ & $\begin{array}{c}3.8 \\
(2.8)\end{array}$ & $\begin{array}{l}28.4 \\
(9.4)\end{array}$ & $\begin{array}{c}8.3 \\
(5.6)\end{array}$ & $\begin{array}{l}0 \\
-\end{array}$ & $\begin{array}{c}8.8 \\
(1.7)\end{array}$ & $\begin{array}{c}5 \\
(0)\end{array}$ & $\begin{array}{l}13.8 \\
(1.7)\end{array}$ & $\begin{array}{c}35 \\
(10.6)\end{array}$ & $\begin{array}{c}6.8 \\
(1.2)\end{array}$ \\
\hline 2 & $\begin{array}{c}22.5 \\
(10.6)\end{array}$ & $\begin{array}{l}0 \\
-\end{array}$ & $\begin{array}{l}2.1 \\
(3)\end{array}$ & $\begin{array}{l}13.3 \\
(3.8)\end{array}$ & $\begin{array}{c}10 \\
(4.2)\end{array}$ & $\begin{array}{l}2.1 \\
(3)\end{array}$ & $\begin{array}{c}7.5 \\
(3.5)\end{array}$ & $\begin{array}{c}2.5 \\
(3.5)\end{array}$ & $\begin{array}{l}10 \\
(7)\end{array}$ & $\begin{array}{c}2.5 \\
(3.5)\end{array}$ & $\begin{array}{c}4.5 \\
(6.3)\end{array}$ \\
\hline 3 & $\begin{array}{c}10 \\
(3.5)\end{array}$ & $\begin{array}{l}0 \\
-\end{array}$ & $\begin{array}{c}1.8 \\
(2.4)\end{array}$ & $\begin{array}{c}6.4 \\
(0.8)\end{array}$ & $\begin{array}{l}11.5 \\
(6)\end{array}$ & $\begin{array}{l}0 \\
-\end{array}$ & $\begin{array}{c}7.5 \\
(3.5)\end{array}$ & $\begin{array}{c}1.2 \\
(1.7)\end{array}$ & $\begin{array}{l}0 \\
-\end{array}$ & $\begin{array}{c}1.2 \\
(1.7)\end{array}$ & $\begin{array}{c}3.5 \\
(4.9)\end{array}$ \\
\hline 4 & $\begin{array}{c}5 \\
(3.5)\end{array}$ & $\begin{array}{c}0.8 \\
(0.8)\end{array}$ & $\begin{array}{c}1.5 \\
(2.1)\end{array}$ & $\begin{array}{l}2.1 \\
(3)\end{array}$ & $\begin{array}{c}7.9 \\
(1.2)\end{array}$ & $\begin{array}{l}0 \\
-\end{array}$ & $\begin{array}{c}3.8 \\
(5.3)\end{array}$ & $\begin{array}{l}0 \\
-\end{array}$ & $\begin{array}{c}1.2 \\
(1.7)\end{array}$ & & \\
\hline Total & 100 & 0.8 & 9.2 & 50.2 & 37.7 & 2.1 & 27.6 & 8.7 & 25 & 38.7 & \\
\hline
\end{tabular}

ce: cervix; he: head; th: thorax; ab: abdominal segms.; al: anal lobe; metac: metacercariae; $\mathrm{L}_{4}$ : larvae; PP: pre-pupa; P: pupa 
In this experiment with larvae grouped for only $24 \mathrm{~h}$, the mortality rate was slightly higher $(61.3 \%)$ than in the previous experiments with Ae. albopictus larvae exposed individually to two different densities of cercariae (58\% and $43.4 \%$ respectively), but with no significant differences $(p>0.05)$. The mortality obtained for $24 \mathrm{~h}$ exposition was practically the same as that obtained by Carvalho et al. (2001a) for larvae exposed and maintained in groups $(61.1 \%)$.

Regarding the place metacercariae were found, the greater mean percentage was in the thorax $[39.7 \%(\mathrm{SD}=$ $10.7)]$, and in the abdominal segments [35.2\% $(\mathrm{SD}=4.7)]$, followed by that for the head [21.4\% (SD = 15.1)], and with a small amount being found in the anal lobe [3.3\% $(\mathrm{SD}=1.3)]$ and cervix $[0.4(\mathrm{SD}=0.4)]$.

\section{DISCUSSION}

The result of this study was similar to the results presented by Carvalho et al. (2001a); infected Ae. albopictus larvae also showed in this study a delayed development, with the individuals mainly dying as larvae (41.7\%), followed by as pre-pupae (13.8\%) or as pupae $(2.5 \%)$ when exposed individually to 1.66 xiphidiocercariae/ml. Percentage of infected larvae was always $100 \%$, percentage of final mortality for Ae. albopictus was very close, being $61.1 \%$ in that study and $58 \%$ here, and the delay for last instar larvae in becoming adults was also very close, being 1.4 times in that former study and between 1.35 and 1.67 times in the present. It must be considered that both experiments differed by the exposition time and cercariae concentration. In the present case each larva was isolated in a flask, and in that case they were grouped in 20 individuals.

Comparing the two experiments realized with individualized exposition, it can be noted that both concentrations (5 or 10 xiphidiocercariae/larva) produced essentially the same results. It was observed high mortality in larvae individualized or grouped exposed. It can be concluded that such densities of cercariae per volume (or per larva) are high, determining a total rate of infection, and elevated final mortality.

Despite the number of cercariae being the same (10), in the experiment where the larvae were individually exposed, the larvae were dispersed in $6 \mathrm{ml}$ of water, while in the experiment involving exposition of grouped larvae, 40 larvae were placed in $40 \mathrm{ml}$ water, thus showing that confined larvae are less susceptible.

It was observed in this study that just one cercaria may kill a last instar Ae. albopictus larva, depending on the place where it encysted, with the most critical locations being the head and the thorax. For such parasitism, the place of the metacercariae can be so just as important as their amount. In addition to absorbing nutrients in sensitive places, the cercariae may also impose a mechanical action compressing organs and structures essential for survival or for adult formation. This suggests that the number of penetrating xiphidiocercariae in addition the body region also play a role in determining the extent of malformation.

When adults resulting from treated larvae were squashed for microscopic examination of their tissues, it was observed that they always contained live metacercariae, strongly suggesting that adults could play an important role as dispersing of the parasite.

The results described in this paper are in agreement with studies carried out by Dollfus et al. (1960), Rao et al. (1985), Weber et al. (1987a,b,c), Zakikhani and Rau (1999) and Carvalho et al. (2001a), which indicate that the cercariae belonging to trematodes of the genus Haematoloechus as well as those from Plagiorchis and Prosthogonimus, are all of great potential for mosquito biological control, once they proved to be highly efficient against some evaluated mosquito species. It must be noted however that such digenetic trematodes require as a prerequisite, that intermediate (snail and mosquito) and definitive (vertebrate) hosts exist in the same environment. Breeding places such as those used by many Anopheles and Culex species, are among the ones with the adequate size and ecological complexity to maintain these trematodes hosts, and could be considered for control programs. On the other hand, even some natural breeding places used by Ae. albopictus may not be considered, such as bamboo stumps (Andrade, pers. commun., Neves \& Silva 1989), bromeliads (Andrade, pers. commun., Forattini et al. 1998a) and holes on tree roots (Andrade, pers. commun.) or on the ground (Forattini et al. 1998b). The man-made small containers used by Ae. aegypti are far so from possible candidates. From the safety point of view, the impact of xiphidiocercariae on non-target species still requires a lot of studies, especially when referring to species of the genera Plagiorchis and Haematoloechus, whose definitive hosts are respectively mammals and amphibians.

\section{ACKNOWLEDGEMENTS}

To Ivo G Pereira and João Batista A de Oliveira, Dept. of Parasitology, Unicamp, and to Takako U Fujii, Alberto J dos Santos and Antônio L de Mendonça, of the Biological Institute, Registro, São Paulo.

\section{REFERENCES}

Andrade CFS 1995. Manejo integrado de mosquitos. I Sem Nac Pragas Urbanas e Saúde Pública, p.12-22.

Blankespoor HD 1977. Notes on the biology of Plagiorchis noblei Park, 1936 (Trematoda: Plagiorchiidae). Proc Helminthol Soc 44: 44-50.

Busta J, Nasincova V 1986. Plagiorchis neomidis, new record (Trematoda: Plagiorchiidae) in Czechoslovakia and studies on its life cycle. Prague 33: 123-129.

Carvalho GA, Andrade CFS, Ueta MT 2001a. Susceptibilidade de três espécies de mosquitos (Diptera, Culicidae) ao parasitismo por xifidiocercárias (Trematoda). Entomol Vect 8: 105-120.

Carvalho GA, Ueta MT, Andrade CFS 2001b. Búsqueda de xifidiocercarias (Trematoda) en moluscos de agua dulce recolectados en nueve municipios del Estado de São Paulo, Brasil. Bol Chil Parasitol 56: 3-9.

Carvalho GA, Ueta MT, Andrade CFS 2001c. Estudios morfométricos y biológicos de xifidiocercarias (Trematoda) provenientes de la infección natural de Lymnaea columella Say, 1817 (Basommatophora, Lymnaeidae) y Biomphalaria tenagophila Orbigny, 1835 (Basommatophora, Planorbidae) recolectados en Miracatu, Estado de São Paulo, Brasil. Bol Chil Parasitol 56: in press. 
Dempster SJ, Rau ME 1991. Plagiorchis noblei (Plagiorchiidae) in Aedes aegypti: Parasite acquisition and host mortality in trickle infections. J Parasitol 77: 111-112.

Dollfus RP, Doby JM, Laurent P 1960. Sur une xiphidiocercaire parasitant Limnaea truncatula (O. F. Muller) en HauteSavoie et s'enkystant dans des larves de moustiques. Bull Soc Zool France 85: 331-347.

Finney JR 1979. Mermithids for mosquito control. Proc Annu Meet Utah Mosq Abatement Assoc 32: 29.

Forattini OP, Marques GRAM, Kakitani I, Brito M, Sallum MAM 1998a. Significado epidemiológico dos criadouros de Aedes albopictus em bromélias. Rev Saúde Pública 32: 186-188.

Forattini OP, Marques GRAM, Kakitani I, Brito M, Sallum MAM 1998b. An unusual ground larval habitat of Aedes albopictus. Rev Inst Med Trop S Paulo 40: 121-122.

Hominick WM, Tingley GA 1984. Mermithid nematodes and the control of insects vectors of human disease. Biocontrol News Inform 5: 7-21.

Kay BH, Cabral CP, Sleigh AC, Brown MD, Ribeiro ZM, Vasconcelos AW 1992. Laboratory evaluation of Brazilian Mesocyclops for mosquito control. J Med Entomol 29: 599602.

Lacey LA, Orr BK 1994. The role of biological-control of mosquitoes in integrated vector control. Am J Trop Med Hyg 50: 97-115.

Melo AS, Macedo ACC, Andrade CFS 1996. Eficiência de Dugesia tigrina (Girardia) (Turbellaria: Tricladida) como agente controlador de imaturos do mosquito Aedes albopictus (Skuse) em pneus-armadilha. An Soc Entomol Brasil 25: 321-327.

Neves DP, Silva RF 1989. Aspectos da biologia do Aedes albopictus (Skuse, 1894) (Diptera: Culicidae), em nível de campo. Mem Inst Oswaldo Cruz 84: 403-404.

Petersen J 1973. Role of mermithid nematodes in biological control of mosquitoes. Exp Parasitol 3: 239-247.

Rao PV, Babu R, Gurappa K, Kumar AG 1985. Larval mosquito control through deployment of xiphidiocercariae. $J$ Invert Pathol 46: 1-4.

Rau ME, Ahmed SS, Lewis DJ 1991. Impact of the entomophilic digenean Plagiorchis noblei (Trematoda: Plagiorchiidae) on the survival of Aedes provocans under field conditions. J Am Mosq Control Assoc 7: 194-197.

Van Theil PH 1930. Die Entwicklung von Agamodistomun anopheles zum Pneumonoeces variegatus Rud. Zentralb Bakt u Infektkr 117: 103-112.

Webber RA, Rau ME, Lewis DJ 1987a. Susceptibility of Aedes aegypti and Anopheles quadrimaculatus larvae to infection with the cercariae of Plagiorchis noblei (Trematoda: Plagiorchiidae). J Am Mosq Control Assoc 3: 193-195.

Webber RA, Rau ME, Lewis DJ 1987b. The effects of Plagiorchis noblei (Trematoda: Plagiorchiidae) metacercariae on the behavior of Aedes aegypti larvae. Can J Zool 65: 1340-1342.

Webber RA, Rau ME, Lewis DJ 1987c. The effects of Plagiorchis noblei (Trematoda: Plagiorchiidae) metacercariae on the susceptibility of Aedes aegypti larvae to predation by guppies (Poecilia reticulata) and meadow voles (Microtus pennsylvanicus). Can J Zool 65: 2346-2348.

Yoder HR, Coggins JR 1998. Larval trematode assemblages in the snail Lymnaea stagnalis from southeastern Wisconsin. J Parasitol 84: 259-268.

Zakikhani M, Rau ME 1999. Plagiorchis elegans (Digenea: Plagiorchiidae) infections in Stagnicola elodes (Pulmonata: Lymnaeidae): host susceptibility, growth, reproduction, mortality, and cercarial production. J Parasitol 85: 454-463. 